\title{
Nursing Care in Polycythemia Vera: A Review Article
}

\section{Ozkaraman $\mathrm{A}^{1 *}$, Babadag $\mathrm{B}^{1}$ and Tuna $\mathrm{HI}^{2}$}

${ }^{1}$ Eskişehir Osmangazi University, Faculty of Health Sciences, Department of Nursing, Eskişehir, Turkey

${ }^{2}$ Selcuk University, Aksehir Kadir Yallagoz High School of Health, Konya, Turkey

\begin{abstract}
Background: Polycythemia vera (PV) is a chronic myeloproliferative neoplasm, which is a threat to life. Teamwork is needed during the process of treatment and care of patients suffering from PV, which is a chronic illness. Especially, important roles fall to the nurses within the team.

Objective: The purpose of this article is to assess the symptoms in connection with $\mathrm{PV}$ and the treatment and the difficulties which have been experienced, in accordance with the System for the Categorisation of Nursing Diagnoses of the North American Nursing Diagnosis Association (NANDA) and present possible nursing diagnoses and the management of symptoms according to these diagnoses.

Methods: This review article was carried out by have been scanned with the search terms PV, care and nursing in PubMed databases, $\mathrm{CINAHL}^{\circledR}$, Ebsco Academic Search Complete, Scopus and Scholar Google databases. The approaches directed at the nursing diagnoses which have been determined in the article, are based on the papers from peer-reviewed publications, books, guidelines and the recommendations made by medical professionals.

Results and conclusion: The important nursing diagnosis related with PV are altered gas exchange, altered tissue perfusion, fatigue, high risk of injury, high risk of infection, deterioration of comfort (itching), high risk of impaired skin integrity and pain. It was not possible to find any randomized controlled studies on this subject. It is recommended that these diagnosis and differences are taken into account in nursing interventions. Nurses need to use a patient centred approach in the administration of PV, in order to assess the patients, plan care and achieve the self-management of the disease with the patient, who has been empowered with knowledge.
\end{abstract}

Keywords: Polycythemia vera; Nursing care; Nursing diagnosis

\section{Introduction}

Polycythemia vera (PV) is a chronic myeloproliferative neoplasm, which is characterised with the clonal proliferation of the erythroid, myeloid and megakaryocytic series and which is a threat to life $[1,2]$. The foundation is prepared for the formation of blood clots in all of the tissues and organs, together with an increase in the viscosity and volume of blood in particular, and many systems such as the central nervous system and the cardiovascular and gastrointestinal systems are affected $[1,3]$. While PV, which increases with age, is seen in a rate of 10.9 out of every one million people in America [4], it has not been possible to reach data on the incidence of the illness in Turkey. According to the diagnosis criteria of the World Health Organisation, 2 major and 1 minor or 1 major and 2 minor criterion need to be present at the same time for a diagnosis of PV. The major criteria are haemoglobin levels in men being $>18.5 \mathrm{~g} / \mathrm{dl}$ and $>16.5 \mathrm{~g} / \mathrm{dl}$ in women, or the presence of the other findings of increased masses; and the positivity of other functionally similar mutations, such as the JAK2 and V61F7 or JAK2 Exon 12 mutation. The minor criteria, on the other hand, are a bone marrow biopsy displaying hyper-cellularity based on age, lower than normal serum erythropoietin levels and the formation of in vitro endogenous erythroid colonies [5].

The symptoms in polycythemia patients are generally asymptomatic, while generally being headaches due to hyper-viscosity and hypervolemia, as well as nose bleeds, tinnitus, vertigo, vision disorders, dyspnoea, angina, a florid appearance and a burning sensation in the hands and feet. Additionally, symptoms of petechia, purpura, ecchymosis, splenomegaly, hepatomegaly, peptic ulcers and hyperuricaemia are seen [6,7]. Cardiovascular risk factors (hypertension, hypercholesterolemia, diabetes, smoking) increase the risk of complications in advanced ages in particular [5,8]. According to the information relayed from Barbui and Finazzi, while thrombotic incidents develop in $38.4 \%$ ( $n=1638$ ) of PV patients, $41 \%$ of deaths in $\mathrm{PV}$ develop as a result of cardiovascular incidents, $13 \%$ as a result of PV turning into a haematological illness such as acute leukaemia and $4 \%$ as a result of major bleeding [8].

The treatment of polycythemia is planned by the physician according to the risk category of the patient $[5,8]$. Depending on the risk group of the patient, aspirin, phlebotomy and cyto-reduction treatments (interferon alpha (IFN- $\alpha$ ), hydroxyurea, radioactive phosphorus, alkalising agents, anagrelide) and supporting treatments are implemented $[5,6,8]$. However, certain side effects may emerge, as well as the benefits of the treatments. Therefore, it is important for the nurses who implement the treatments to be careful on this matter and to be able to manage the symptoms.

While 75-100 mg/day aspirin and phlebotomy is implemented on patients in the low risk group (unless there are contraindications) in order to prevent thrombosis, high risk patients, those who are unable to tolerate phlebotomy and those in progressive circumstances are given cyto-reduction treatment $[1,5]$. Stomach disorders and bleeding may develop in patients due to the use of aspirin, while iron deficiency, exhaustion, symptoms of confusion, nausea-vomiting, difficulty in

*Corresponding author: Ayse Ozkaraman, Eskisehir Osmangazi Univercity Faculty of Health Sciences, Department of Nursing, Meselik Campus, Odunpazarı, Eskisehir 26480 Turkey, Tel: 90.222.2393750-1526; E-mail: aozaydin26@hotmail.com

Received: August 08, 2016; Accepted: September 21, 2016; Published: September 30, 2016

Citation: Ozkaraman A, Babadag B, Tuna HI (2016) Nursing Care in Polycythemia Vera: A Review Article. J Pat Care 2: 121. doi: 10.4172/2573-4598.1000121

Copyright: (C) 2016 Ozkaraman A, et al. This is an open-access article distributed under the terms of the Creative Commons Attribution License, which permits unrestricted use, distribution, and reproduction in any medium, provided the original author and source are credited. 
reaching the peripheral vein, bruising in the needle puncture site following the procedure, hematoma, arm pain and more rarely, anaemia and heart disease may develop in connection with phlebotomy $[9,10]$. The hydroxyurea used in the treatment of the patients in the medium-high risk group is generally well tolerated by patients, but changes in the skin (loss of hair, hyperpigmentation, erythema, atrophy on the skin, changes in the nails, leg ulcerations) and secondary malignancies do emerge depending on the dose [8,11-13]. IFN- $\alpha$ is mostly recommended in high risk patients below the age of 40 , women in the reproductive age group, who have and are unable to use cytoreductive medication due to its teratogenic effects and for those who suffer from severe itching. The use of IFN- $\alpha$ may result in side effects such as symptoms similar to influenza, which will require the use of paracetamol, weariness, myalgia, weight loss, depression in long term use and ischaemic, infectious, cardiovascular and gastrointestinal side effects [8]. Busulfan, which is generally used in the treatment of elderly patients, is potentially carcinogenic and leads to a decrease in the number of blood cells by putting pressure on the bone marrow $[12,14]$. Due to its mutagenic effect, nurses, who prepare and apply busulfan need to place importance in chemotherapy practices.

Teamwork is needed during the process of treatment and care of patients suffering from PV, which is a chronic illness. Important roles fall to the nurses within the team, in the assessment of the patient, the continuation of the treatment, the monitoring of possible side effects, the control of the symptoms and the education of the patients. The purpose of this article is to assess the symptoms which are frequently seen in patients who have been diagnosed with PV, in connection with the illness and the treatment and the difficulties which have been experienced, in accordance with the System for the Categorisation of Nursing Diagnoses of the North American Nursing Diagnosis Association (NANDA) and present possible nursing diagnoses and the management of symptoms according to these diagnoses.

\section{The Management of Symptoms in Polycythemia Vera}

\section{Evaluation}

Nurses should obtain the detailed history of PV patients; carry out a physical examination to obtain a medical diagnosis and collect the data related to the diagnosis tests. In the patient history, the existing illnesses, the thrombotic incidents which have been suffered (cerebral ischaemic attacks, myocardial infarctions, venous thrombosis, etc.), the cardiovascular risk factors (hypertension, diabetes mellitus, smoking, age), the medication used, previous surgical operations which increase the risk of thromboembolism, pregnancy and other malignant situations such as cancer should be questioned $[1,5,8,15,16]$.
The potential subjective (local pains, joint pains, headaches, vertigo, numbness in the extremities, apathy, chest pains, increased heart beat) and objective (paresthaesia, clouding of consciousness, thrombus, emboli, angina) findings related to thromboembolism and the risk of deep vein thrombosis (DVT) need to be evaluated in polycytemia patients $[16,17]$. The "Autar DVT Risk Diagnosis Scale", the use of which is suitable for polycythemia patients, can be used in order to determine the risk of DVT [17]. The risk of bleeding due to the use of high doses of aspirin and/or acquired von Willebrand Disease, increases in PV $[6,7,18]$. In order for bleeding to be able to be detected early and the necessary precautions to be taken in a timely manner in clinics, the risk of bleeding and bleeding should be evaluated based on the NCICTCAE version 4.03 classification criteria [19]. The speed, quality, depth and manner of and the effort expended for respiration, the colour and temperature of the skin, the mucous membranes and the nail beds should be observed during the physical examination of the patient, and the vital findings and mental status should be assessed and recorded $[20,21]$. In addition to this, the performance of the patient during the physical examination should be assessed using the Karnofsky or ECOG Performance Scale, and the level of weariness should be determined with a visual analogue scale [22].

When the symptoms which have developed and the difficulties experienced in PV, due to the illness ad treatment process are evaluated, it is considered that some nursing diagnoses may be seen in the patients. It has been foreseen that altered gas exchange, altered tissue perfusion, fatigue, high risk of injury, high risk of infection, deterioration of comfort (itching), high risk of impaired skin integrity and pain diagnoses by nurses (which have been stated in the NANDA Nursing Diagnoses Classification System) could be seen frequently in $\mathrm{PV}$, and the patient care plan, set out below, has been prepared [23]

\section{Nursing care}

The findings connected to PV and its treatment is matters which reduce the quality of life and limit daily living activities. It is possible to increase the quality of life of patients by managing the symptoms. Randomized controlled studies, which examine the impact of approaches in connection with symptom management in PV, have been scanned with search terms PV, care, and nursing in PubMed databases, CINAHL $^{\circledR}$, Ebsco Academic Search Complete, Scopus and Scholar Google databases, but it was not possible to find any randomised controlled studies on this subject. Therefore, the approaches directed at the nursing diagnoses which have been determined in the article, are based on the papers from peer-reviewed publications, books, guidelines and the recommendations made by medical professionals (Table 1).

The presence of cardiovascular risk factors together with age

\begin{tabular}{|c|c|c|}
\hline Etiology & $\begin{array}{l}\text { Nursing } \\
\text { Diagnosis }\end{array}$ & Approach \\
\hline $\begin{array}{l}\text { - Altered in the flow of blood due } \\
\text { to thrombosis }\end{array}$ & $\begin{array}{l}\text { Altered gas } \\
\text { exchange }\end{array}$ & $\begin{array}{l}\text { - The pace and depth of the respiration, the respiratory sounds and the vital signs of the patient should be } \\
\text { evaluated and the consciousness of the patient monitored }[20,21] \text {. } \\
\text { - The head of the patient should be raised, putting him/her into as suitable position and ensuring bed rest [24]. } \\
\text { - If the patient is not conscious, safety measures should be taken against the risk of trauma. } \\
\text { - A patient with respiratory difficulties should be made to sit on the edge of the bed and his/her arms should clasp } \\
\text { the pillow on the dining table or he/she should be made to sit on a chair, separate his/her feet and recommended } \\
\text { to rest by placing his/her hands on his/her knees [24]. } \\
\text { - The patient should be taught to use relaxation techniques and deep breathing exercises, and made to use them } \\
\text { [24,25]. } \\
\text { - Hydration should be ensured according to the wishes of the physician (2-3 L of liquid should be given per day, } \\
\text { if there is no risk of cardiopulmonary overload and contraindications such as renal dysfunction) and the liquid } \\
\text { intake and excretions should be monitored [24]. } \\
\text { - Oxygen treatment should be started for the patient [26]. }\end{array}$ \\
\hline
\end{tabular}




\begin{tabular}{|c|c|c|}
\hline $\begin{array}{l}\text { - Hypervolemia } \\
\text { - Altered in the flow of blood due } \\
\text { to thrombosis }\end{array}$ & $\begin{array}{l}\text { Altered tissue } \\
\text { perfusion }\end{array}$ & $\begin{array}{l}\text { - The patient should be assessed from the point of view of confusion, uneasiness, dyspnoea, arrhythmia, } \\
\text { tachycardia and cyanosis due to cerebral ischaemic attacks [9] and the changes in the extremities and skin } \\
\text { (changes in temperature and colour, inability to take the pulse, pain, etc.) should be monitored against the } \\
\text { possibility of peripheral ischaemic attack [27]. } \\
\text { - The patient should be placed in the semi-fawler's position prior to phlebotomy, his/her vital signs, especially } \\
\text { blood pressure, should be assessed and it should be ensured that the patient does not stand up as soon as the } \\
\text { procedure is completed, he/she should be monitored from the point of view of signs of hypervolemia and the } \\
\text { intake of liquid during the } 24 \text { h after the procedure should be increased [28]. } \\
\text { - Early ambulation and passive leg exercises should be ensured in order to prevent thrombotic incidents and the } \\
\text { position of the patient should be changed every hour [9]. } \\
\text { - Interventions should be made to improve venous blood flow in the patient and with this purpose, the patient } \\
\text { should be prevented from sitting in a cross-legged fashion, placing a cushion under his/her knee, wearing tight } \\
\text { clothes, and going on lengthy car or aircraft journeys [26,29,30]. } \\
\text { - The skin of the patient should be moistened [29,30]. } \\
\text { - Hydration should be increased according to the wishes of the physician, in order to reduce the blood viscosity } \\
\text { of the patient [26]. }\end{array}$ \\
\hline $\begin{array}{l}\text { - Hyper-viscosity } \\
\text { - Acquired Von Willebrand } \\
\text { disease } \\
\text { - Anti-thrombolytic treatment }\end{array}$ & $\begin{array}{l}\text { The risk of } \\
\text { wounding }\end{array}$ & 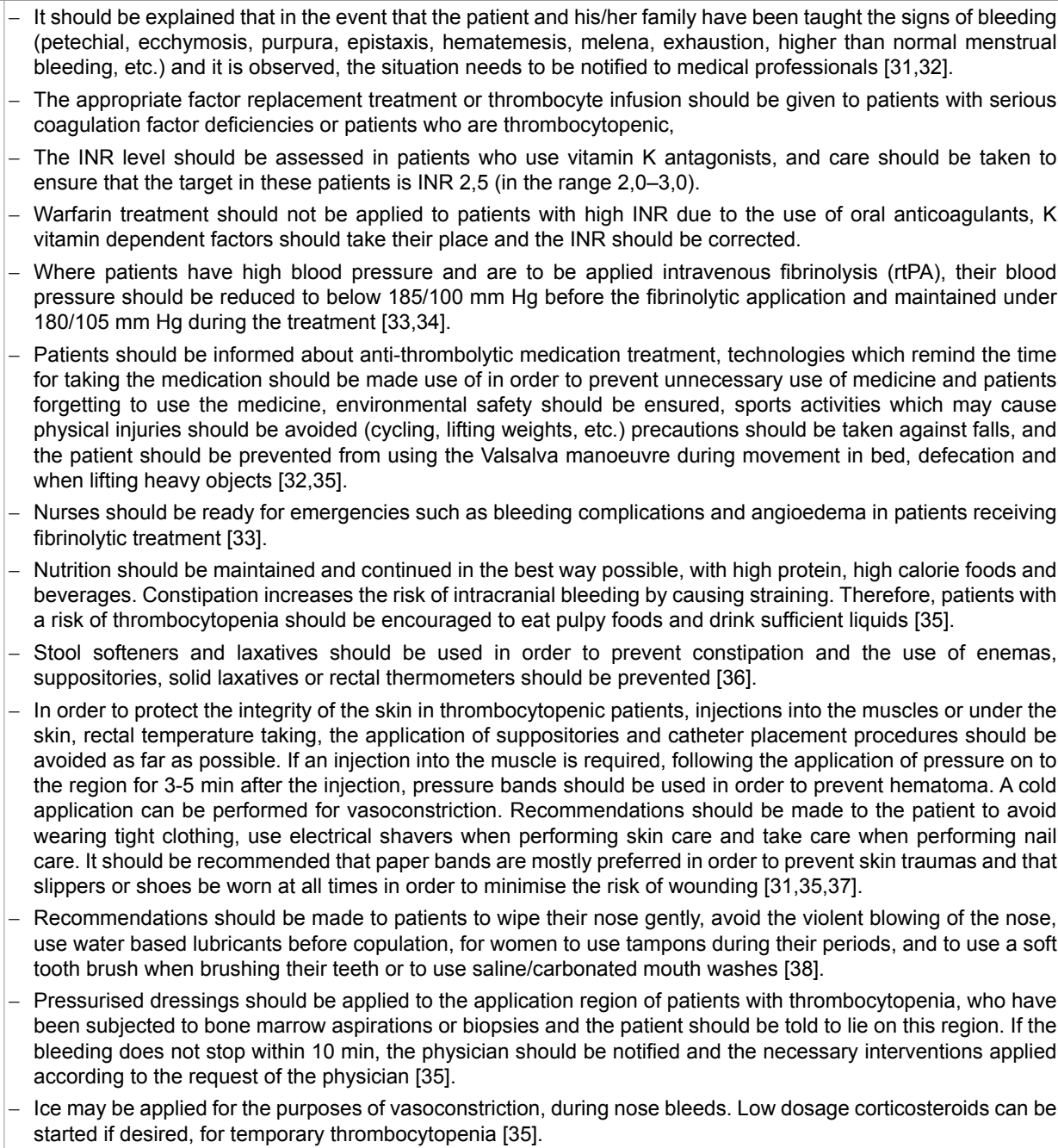 \\
\hline $\begin{array}{l}\text { - alkalizing agents, in connection } \\
\text { with IFN- } \alpha \text { treatment }\end{array}$ & $\begin{array}{l}\text { The risk of } \\
\text { infection }\end{array}$ & $\begin{array}{l}\text { - Patients being given IFN- } \alpha \text { and busulfan should be monitored due to the risk of infection, and patients with fever } \\
\text { and neutropenia should be evaluated in order to reduce the risk of possible complications [39,40]. } \\
\text { - Side effects such as influenza like symptoms (fever, myalgia, headaches, vertigo, nausea/vomiting, diarrhoea, } \\
\text { etc.), weariness, myelosuppression and anorexia in patients should be observed and these symptoms and the } \\
\text { tracking of fever should be taught to the patient and his/her family for the purposes of early detection. } \\
\text { - The blood values, fever, pulse and other vital signs of the patient should be monitored, } \\
\text { - Where myelosuppression is high, there should be cooperation with the physician, and where necessary, the } \\
\text { dosage of the medication organised on the request of the physician or the treatment should be paused. } \\
\text { - Sufficient intake of fluids should be ensured in order to prevent dehydration, and the importance liquid intake } \\
\text { should be explained to the patient. Where necessary IV hydration should be provided [41]. } \\
\text { - Care should be shown to hand and respiratory hygiene, and the practices on this subject should be taught to } \\
\text { the patient and his/her family, } \\
\text { - Unnecessary invasive procedures should be avoided [42]. }\end{array}$ \\
\hline
\end{tabular}




\begin{tabular}{|c|c|c|}
\hline $\begin{array}{l}\text { - Distortion in the flow of blood } \\
\text { - Phlebotomy } \\
\text { - Iron deficiency }\end{array}$ & Fatigue & $\begin{array}{l}\text { - The impact of the fatigue being experienced by the patient on his/her daily activities and functional status should } \\
\text { be assessed and recorded on the nurse observation form [43,44]. } \\
\text { - A routine sleeping plan should be created in order to increase the sleep quality of the patient. In the sleeping } \\
\text { plan of the patient, he/she should be prevented for sleeping for long periods and more than } 20 \text { min during the } \\
\text { day and recommendations should be made not to use alcoholic and caffeine containing beverages before going } \\
\text { to bed to perform relaxation exercises } 1 \mathrm{~h} \text { before going to bed }[45,46] \text {. } \\
\text { - The physical therapy specialist should be consulted in order to establish an individual exercise programme } \\
\text { which takes into account the illness and the functional status of the individual }[47,48] \text {. } \\
\text { - The patient should be asked to keep a diary in order to monitor his/her level of exhaustion }[49] \text {. } \\
\text { - The patient should be trained on the subjects of energy maintenance and activity planning and it should be } \\
\text { ensured that this information is integrated into the patient's lifestyle }[46,50] \text {. } \\
\text { - Patients being given oral iron treatment should be observed for side effects and given information on this subject } \\
\text { [51]. }\end{array}$ \\
\hline $\begin{array}{l}\text { - Hyperviscosity } \\
\text { - Hyperuricaemia }\end{array}$ & $\begin{array}{l}\text { Deterioration of } \\
\text { comfort, itching }\end{array}$ & $\begin{array}{l}\text { - A cool and lukewarm bath should be recommended in order to relieve itching in the patient }[26,52] . \\
\text { - Rubbing and scrubbing the skin should be avoided in order to minimise any possible irritation to the skin. } \\
\text { - The skin should be moisturised using oily creams [52]. } \\
\text { - Antihistamines requested by the physician should be provided [52]. }\end{array}$ \\
\hline $\begin{array}{l}\text { - Hyperuricaemia } \\
\text { - Busulfan } \\
\text { - IFN- } \alpha \\
\text { - Hydroxyurea treatment }\end{array}$ & $\begin{array}{l}\text { Deterioration of } \\
\text { the integrity of the } \\
\text { skin (hair loss, } \\
\text { changes in the } \\
\text { skin of the hand } \\
\text { and feet and the } \\
\text { nails) }\end{array}$ & $\begin{array}{l}\text { - The patients should informed that they could suffer hair loss due to IFN- } \alpha \text { and busulfan, but that their hair could } \\
\text { regrow 1-2 months after the treatment has been completed, and explanations directed at preventative measures } \\
\text { (preferring pH neutral baby shampoos for hair care, not using hair styling equipment, hair dryers, hair sprays and } \\
\text { hair dyes, the greasing of the hair when it is being lost, the use of wide toothed combs when combing hair and } \\
\text { the avoidance of vigorous combing) should be made. } \\
\text { - The physical image of patients should be assessed and where necessary hair should be cut prior to treatment. } \\
\text { - Patients should be advised to make use of attire such as a bandana, wig, shawl and hat and where necessary, } \\
\text { encouraged participating in social activities. } \\
\text { - Appropriate opportunities should be created for patients suffering from hair loss to share their feelings, such as } \\
\text { fear, anger, sadness and shame and they should be encouraged to share their feelings [53]. } \\
\text { - Nurses should carry out routine evaluations to check for numbness, tingling, change of colour, deterioration } \\
\text { in the integrity of the skin and dryness of the skin in the hands and feet, change of colour in the nail beds and } \\
\text { nails, and breakages in the nails, as a result of the changes which may develop in the hands and feet due to } \\
\text { chemotherapy. } \\
\text { - The patient should be taught to avoid high temperatures and chemicals and applying excess loads on the hands } \\
\text { and feet, moisturise using creams containing lanolin, cut nails short and wash hands and feet with lukewarm } \\
\text { water and dry them, in order to maintain the health of the skin of his/her hands and feet and nails. Wound care } \\
\text { should be implemented and the pain treated in the event that the integrity of the skin has deteriorated [54]. }\end{array}$ \\
\hline $\begin{array}{l}\text { - Distortion in the flow of blood } \\
\text { due to thrombosis } \\
\text { - The application of phlebotomy } \\
\text { - The implementation of } \\
\text { parenteral medication }\end{array}$ & Pain & $\begin{array}{l}\text { - A comprehensive pain assessment should be carried out. } \\
\text { - Non-pharmacological methods to deal with pain should be utilised (paying attention to something else, listening } \\
\text { to music, etc.). } \\
\text { - The physical environment should be ensured, in respect of sound, lighting and noise [55]. } \\
\text { - It should be taken into account that the patient may experience pain due to thrombosis, and peripheral pulse } \\
\text { control should be performed for this purpose [16,17,56]. } \\
\text { - The patient should be given information prior to phlebotomy, and the phlebotomy should be performed by } \\
\text { experienced and well-trained personnel. } \\
\text { - The size of the needle used should be smaller than the vein chosen during the phlebotomy and if possible the } \\
\text { antecubital region should be selected [57]. } \\
\text { - The Buzzy application, which ensures the application of cold and vibrations, can be used during the phlebotomy. } \\
\text { This should be applied with care due to its ability to affect the blood parameters and create sensitivity in the skin } \\
\text { where it is applied [58]. } \\
\text { - Should the patient be aged, sleepy or have cognitive and perceptive disorders, this could increase the risk of } \\
\text { IV complications as well as cause pain due to the implementation of the medicine. Therefore, these need to } \\
\text { be taken into consideration prior to the application of busulfan and if possible the medication should be applied } \\
\text { through the large veins on the forearms, while regions close to the joints, the antecubital fossa and the veins on } \\
\text { the back of the hand should be avoided, and it is recommended that frequent monitoring is performed in order to } \\
\text { be able to prevent extravasation during the application and to become aware of it early [59,60]. }\end{array}$ \\
\hline
\end{tabular}

Table 1: The nursing process in polycythemia vera.

increases the probability of complications developing in patients suffering from polycythemia. Therefore, consultancy services provided by nurses on the subjects of the planning of training on behaviour which will improve health, the structuring of diet and exercise programmes and the abandoning of habits which are damaging to health, such as smoking and alcohol, will both be able to prevent the loss of capabilities related to complications and reduce mortality rates.

\section{Conclusion}

Nurses need to use a patient centred approach in the administration of PV, in order to assess the patients, plan care and achieve the self- management of the disease with the patient, who has been empowered with knowledge.

\section{References}

1. Raedler LA (2014) Diagnosis and management of polycythemia vera: Proceedings from a Multidisciplinary Roundtable. Am Health Drug Benefits 7: S36-47.

2. McMullin MF (2007) A review of the therapeutic agents used in the management of polycythaemia vera. Hematol Oncol 25: 58-65.

3. Kvasnicka HM, Thiele J (2010) Prodromal myeloproliferative neoplasms: The 2008 WHO classification. American Journal of Hematology 85:62-69. 
4. Srour SA, Devesa SS, Morton LM, Check DP, Curtis RE, et al. (2016) Incidence and patient survival of myeloproliferative neoplasms and myelodysplastic/ myeloproliferative neoplasms in the United States, 2001-2012. Br J Haemato 7: 1-15.

5. Türk Hematoloji Dernegi (2010) Kronik miyeloproliferatif hastaliklarda tani ve tedavi klavuzu 1

6. Karakus S (2012) Polycythemia vera.

7. Greenberg H (2013) Polycythemia vera: An evidence-based examination from a nursing perspective. Crit Care Nurs Q 36: 228-232.

8. Barbui T, Finazzi G (2006) Evidence-based management of polycythemia vera Best Pract Res Clin Haematol 19: 483-493.

9. Tefferi A (2003) Polycythemia vera: A comprehensive review and clinical recommendations. Mayo Clin Proc 78: 174-194.

10. Assi TB, Baz E (2014) Current applications of therapeutic phlebotomy. Blood Transfus 12: S75-S83.

11. Daoud MS, Lawrence EG, Pittelkow MR (1997) Hydroxyurea dermopathy: A unique lichenoid eruption complicating long-term therapy with hydroxyurea Journal of the American Academy of Dermatology 36:178-182.

12. Finazzi G, Barbui T (2007) The treatment of polycythaemia vera: An update in the JAK2 era. Intern Emerg Med 2: 13-18.

13. Shanmugam VK, McNish S, Shara N, Hubley KJ, Kallakury B, et al. (2013) Chronic leg ulceration associated with polycythemia vera responding to ruxolitinib (Jakafi $\left({ }^{\circledR}\right)$. J Foot Ankle Surg 52: 781-785.

14. Yildiz I (2015) Principles of cytotoxic chemotherapy: Oncology nursing. Nobe Bookstore, Istanbul 174-175.

15. Bartley MK (2005) Preventing venous thromboembolism in medical/surgical patients. Nursing Suppl: 16-18.

16. Durmaz Akyol A (2013). Blood disease and nursing care. Meta Printing Services, Izmir 95-100.

17. Autar R (2007) NICE guidelines on reducing the risk of venous thromboembolism (Deep vein thrombosis and pulmonary embolism) in patient undergoing surgery. Journal of Orthopaedic Nursing 11: 169-176.

18. Landolfi R, Nicolazzi MA, Porfidia A, Di Gennaro L (2010) Polycythemia vera Intern Emerg Med 5: 375-384

19. National Institutes of Health National Cancer Institute (2010) NQ-CTCAE 4.03-National Cancer Institute-Common Terminology Criteria for Adverse Events 4.

20. Akyolcu N (2002) Kanserli hastalarda dispne ve hemsirelik bakimi CUHemsirelik Yuksekokulu Dergisi 6: I-8.

21. Ozer CZ (2007) Akciger odemi: Hemsirelik bakim planlari. Ankara, Birlik Printing 157-166.

22. National Comprehensive Cancer Network (2016). NCCN guidelines version cancer related fatigue.

23. Nanda Nursing Diagnosis List (2016) Nursing diagnosis by functional health patterns.

24. Pollovich M, White JM, Kelleher LO (2005) Chemotherapy and biotherapy guidelines and recommendations or practice. Oncology Nursing Society, Pittsburg 167-180.

25. Çil A, Olgun N (2005) Kronik Obstrüktif Akciger Hastaligimin pulmoner rehabilitasyon ile yönetimi. Ege Üniversitesi Hemsirelik Yüksek Okulu Dergisi 21: 103-113

26. Gilbert HS (2001) Current management in polycythemia vera. Semin Hematol 38: $25-28$

27. Michiels JJ, Berneman Z, Schroyens W, van Urk H (2003) Aspirin-responsive painful red, blue, black toe or finger syndrome in polycythemia vera associated with thrombocythemia. Ann Hematol 82: 153-159.

28. Parker DM, Deel PC, Arner SS (2004) Iron out the details of therapeutic phlebotomy. Nursing 34: 46-47.

29. LeMone P, Burke K, Bauldoff G (2011) Medical-surgical nursing: Critica thinking In patient care (5th Edn). Upper Saddle River NJ, Pearson Education.
30. McCance KL, Huether SE (2010) Pathophysiology: The biologic basis for disease in adults and children (6th Ed) Mosby Inc, St. Louis, MO.

31. Gobel HB (2001) Bleeding due to thrombocytopenia. Nursing management of symptoms associated with chemotherapy. Pharmacia Corporation Pittsburgh 165-180.

32. Damron BH, Brant JM, Belansky HB (2009) Putting evidence into practise: Prenvention and management of bleeding in patients with cancer. Clinical Journal of Oncology Nursing 13: 53-583.

33. AHA/ASA Guideline (2015) Guidelines for the management of spontaneous Intracerebral hemorrhage: A guideline for healthcare professionals from the American Heart Association/American Stroke Association. Stroke 46: 2032 2060.

34. Türk Beyin Damar Hastaliklari Dernegi (2015) Inme Tani ve Tedavi klavuzu.

35. Karabuga H, Pinar R (2010) Hematolojik Sorunlar Trombositopeni: Onkoloj Hemsireliginde Kanita Dayali Semptom Yönetimi. Nobel Bookstore, Istanbu 29-34

36. Slichter SJ (2004) Relationship between platelet count and bleeding risk in thrombocytopenic patients. Transfus Med Rev 18: 153-167.

37. Eaton LH, Tipton JM (2009) Putting evidence into practice. Improving oncology patients outcomes. Oncology Nursing Society, Pittsburg. PA.

38. Pereira J, Phan T (2004) Management of bleeding in patients with advanced cancer. Oncologist 9: 561-570.

39. Aapro MS, Bohlius J, Cameron DA, Lago LD, Donnelly JP, et al. (2011) 2010 update of EORTC guidelines for the use of granulocytecolony stimulating factor to reduce the incidence of chemotherapy-induced febrile neutropenia in adult patients with lymphoproliferative disorders and solid tumours. European Journal of Cancer 47:8-32.

40. Flowers CR, Seidenfeld J, Bow EJ, Karten C, Gleason C, et al. (2013) Antimicrobial prophylaxis and outpatient management of fever and neutropenia in adults treated for malignancy: American Society of Clinical Oncology Clinical Practice Guideline. Journal of Oncology Practice 31: 794-810.

41. Rubin KM, Vona K, Madden K, McGettigan S, Braun IM (2012) Side effects in melanoma patients receiving adjuvant interferon alfa-2b therapy: A nurse's perspective. Support Care Cancer. 20:1601-11.

42. Centers for Diesase Control and Prevention (2015) Respiratory hygenie/cough etiquette in healthcare settings.

43. Bower JE, Bak K, Berger A, Breitbart W, Escalante CP, et al. (2002) Screening, assessment and management of fatigue in adult survivors of cancer: An American Society of Clinical Oncology Clinical Practice Guideline Adaptation. J Clin Oncol 1032:1840-1850.

44. Itano JK, Taoka KN (2005) Core curriculum for oncology nursing, Fourth Edition, Elsevier Saunders 15-17.

45. Berger AM, VonEssen S, Khun BR, Piper BF, Arrawal S, et al. (2003) Adherence, sleep and fatigue outcomes after cancer chemotheraphy: Results of a feasibility intervention study. Oncology Nursing Forum 30: 513-522.

46. Yates P, Aranda S, Hargraves M, Mirolo B, Clavarino A, et al. (2005) Randomized controlled trial of educational intervention for managing fatigue in women receiving adjuvant chemotherapy for early stage breast cancer. Journal of Clinical Oncology 23: 6027-6036.

47. Cramp F, Daniel J (2008) Exercise for the management of cancer related fatigue in adults. Cochrane Database of Systematically Review 16: CD006145.

48. Velthuis MJ, Idenburg SCA, Aufdemkampe G, Wittink HM (2010) The effect of physical exercise on cancer fatigue during cancer treatment: A Meta-analysis of randomized controlled trials. Clinical Oncology 22: 208-221.

49. Ream E, Richardson A, Alexander-Dann C (2002) Facilitating patients' coping with fatigue during chemotherapy-pilot outcomes. Cancer Nurs 25: 300-308.

50. Barsevick AM, Dudley W, Beck S, Sweeney C, Whitmer K, et al. (2004) A randomized clinical trial of energy conservation for patients with cancer-related fatigue. Cancer 100: 1302-1310.

51. National Comprhensice Cancer Network (2010) Cancer-related anemia

52. Siegel FP, Tauscher J, Petrides PE (2013) Aquagenic pruritus in polycythemia vera: Characteristics and influence on quality of life in 441 patients. Am Hematol 88: 665-669. 
Citation: Ozkaraman A, Babadag B, Tuna HI (2016) Nursing Care in Polycythemia Vera: A Review Article. J Pat Care 2: 121. doi: 10.4172/25734598.1000121

53. Yangin HB, Özüsaglam E, Can G, Küçücük S (2015) Alopesi: Onkoloji hemsireliginde kanita dayali semptom yönetimi. Nobel Bookstore, Istanbul 187.

54. Yesilbalkan Usta O, Ozkaraman A. El-ayak sendromu ve tirnak degisiklikleri: Onkoloji Hemsireligi. Nobel Bookstore, Istanbul 437-438.

55. Kutlutürkan S. Bedük T (2010) Genel Semptomlar, agri: Onkoloji hemsireliginde kanita dayali semptom yönetimi. Nobel Bookstore, Istanbul 221-229.

56. Büyükyilmaz F, Sendir M (2014) Ameliyat sonrasi bakimda göz ardi edilen bir sorun: Derin ven trombozu (DVT) riskinin tanilanmasi ve hemsirelik bakimi. Journal of Health Sciences. 23: 48-54.
57. World Health Organization (2010) WHO guidelines on drawing blood: Best practices in phlebotomy.

58. Lima-Oliveira G, Lippi G, Salvagno GL, Campelo MD, Tajra KS, et al. (2014) A new device to relieve venipuncture pain can affect haematology test results. Blood Transfus 12: s6-10.

59. Infusion Nursing Standarts of Practice (2011). Journal of Infusion Nursing 34 25-30.

60. Hadaway LC (2004) Preventing and managing peripheral extravasation Nursing 26-27 